University of Nebraska - Lincoln

DigitalCommons@University of Nebraska - Lincoln

USDA National Wildlife Research Center - Staff Publications
U.S. Department of Agriculture: Animal and Plant Health Inspection Service

2018

Island Fox Spatial Ecology and Implications for Management of Disease

Jessica R. Resnik

National Park Service, jessica.resnik@gmail.com

William F. Andelt

Colorado State University

Thomas R. Stanley

USGS

Nathan P. Snow

Colorado State University

Follow this and additional works at: https://digitalcommons.unl.edu/icwdm_usdanwrc

Part of the Life Sciences Commons

Resnik, Jessica R.; Andelt, William F.; Stanley, Thomas R.; and Snow, Nathan P., "Island Fox Spatial Ecology and Implications for Management of Disease" (2018). USDA National Wildlife Research Center - Staff Publications. 2143.

https://digitalcommons.unl.edu/icwdm_usdanwrc/2143

This Article is brought to you for free and open access by the U.S. Department of Agriculture: Animal and Plant Health Inspection Service at DigitalCommons@University of Nebraska - Lincoln. It has been accepted for inclusion in USDA National Wildlife Research Center - Staff Publications by an authorized administrator of DigitalCommons@University of Nebraska - Lincoln. 
Research Article

\title{
Island Fox Spatial Ecology and Implications for Management of Disease
}

\author{
JESSICA R. RESNIK (D), 1,2 Department of Fish, Wildife, and Conservation Biology, Colorado State University, Fort Collins, CO 80523-1474, \\ USA \\ WILLIAM F. ANDELT, ${ }^{3}$ Department of Fish, Wildlife, and Conservation Biology, Colorado State University, Fort Collins, CO 80523-1474, USA \\ THOMAS R. STANLEY, United States Geological Survey, Fort Collins Science Center, Fort Collins, CO 80526, USA \\ NATHAN P. SNOW, ${ }^{4}$ Department of Fish, Wildife, and Conservation Biology, Colorado State University, Fort Collins, CO 80523-1474, USA
}

\begin{abstract}
Disease, predation, and genetic isolation resulted in 4 of 6 island fox (Urocyon littoralis) subspecies being listed as endangered in 2004. Potential for disease outbreaks continues to pose a major threat to the persistence of these isolated, endemic populations. We examined how roads influence the spatial ecology of San Clemente Island foxes (U. l. clementae), particularly in regard to spread of disease, to provide management recommendations for preventing or minimizing a disease outbreak on San Clemente Island, California, USA. Home range areas $\left(\bar{x}=0.75 \mathrm{~km}^{2}\right)$ and core areas $\left(\bar{x}=0.19 \mathrm{~km}^{2}\right)$ of foxes on San Clemente Island were 0.36-1.23 and 2.17 times larger, respectively, than estimates from Santa Cruz Island foxes $(U . l$. santacruzae). Home ranges and core areas were $78 \%$ larger and $73 \%$ larger, respectively, for foxes near roads than for foxes away from roads. Home ranges were also largest when foxes were not caring for offspring (i.e., seasons of pup-independence and breeding). We did not detect any dispersal movements, but foxes living near roads moved 33\% farther in 2-hour periods than foxes not living near roads. Foxes near roads move faster, range more widely, and could more rapidly spread a pathogen throughout the island; therefore, roads might serve as transmission corridors. We recommend reducing this risk by increasing widths of vaccination firewalls (areas where vaccination is used to induce a disease-resistant or immune population of foxes), ensuring these areas deliberately intersect roads, and vaccinating a higher proportion of foxes living near roads. Disease risk models incorporating these strategies could inform the lowest risk scenarios. ( 2018 The Wildlife Society.
\end{abstract}

KEY WORDS Channel Islands, disease, distemper, home range, island fox, rabies, roads, Urocyon littoralis clementae.

The island fox (Urocyon littoralis) occurs as distinct subspecies on 6 of 8 Channel Islands (Collins 1987) in California, USA. Like many insular endemic species, island foxes are especially vulnerable to stochastic events. Four subspecies were placed on the federal endangered species list in 2004 and the International Union for the Conservation of Nature (IUCN) in 2008 designated island foxes as critically endangered throughout their range. Populations of island foxes currently appear stable or increasing on all islands; consequently, the 3 subspecies on San Miguel, Santa Cruz, and Santa Rosa islands were fully de-listed in 2016 and the subspecies on Santa Catalina Island was downlisted to threatened. However, introduced pathogens continue to pose significant risk. Following an outbreak of canine

Received: 23 March 2017; Accepted: 20 February 2018

\footnotetext{
${ }^{1}$ E-mail: jessica.resnik@gmail.com

${ }^{2}$ Current address: National Park Service, Biological Resources Division, Wildlife Conservation Branch, Fort Collins, CO, 80525, USA. ${ }^{3}$ Current address: 2451 County Road J, Crete, NE 68333, USA.

${ }^{4}$ Current address: United States Department of Agriculture, Animal and Plant Health Inspection Service, Wildlife Services, National Wildlife Research Center, Fort Collins, CO 80521, USA.
}

distemper virus in 1999 that decimated the Santa Catalina Island fox (U. l. catalinae) population (Kohlmann et al. 2005, Timm et al. 2009), managers placed increased emphasis on developing response plans for disease epidemics on all islands (Coonan 2012). Concern for the San Clemente Island fox (U. l. clementae) arose after a considerable population decline during 1988 to 2002 (Roemer et al. 2001 a,b; Coonan 2003), the reasons for which are still not well understood. Biologists have expressed concern for all subspecies' lack of resistance to disease (Garcelon et al. 1992, Clifford et al. 2006, Rubin et al.2007), the possibility of immigration by predators (e.g., golden eagles [Aquila chrysaetos]) from the mainland (100 km distant) or other Channel Islands (34-191 km distant), and general vulnerability to stochastic events. Rabies and canine distemper viruses are both highly contagious, fatal diseases transmitted by direct contact (Appel 1987, Fekadu 1991) and are considered by the IUCN and Island Fox Working Group as the diseases most likely to cause extinction of island foxes (Pedersen et al. 2007, Coonan 2011).

Management strategies for rabies and canine distemper generally strive to reduce susceptible hosts, create barriers to spread of disease, or slow transmission. Proactive and reactionary tactics commonly use a high-density vaccinated 
zone of host animals (referred to as a vaccination firewall, immunity barrier, disease barrier, or control zone) that is similar in concept to a firebreak (Slate et al. 2005, Sterner and Smith 2006, Rosatte et al. 2009). Width of a vaccination firewall is determined primarily by the mobility and range of the species involved; this in turn requires knowledge of the species' home range, movement patterns, and movement potential (Wobeser 2007, Rosatte et al. 2010).

Risk of exposure to rabies and canine distemper on San Clemente Island (Clifford et al. 2006) prompted the initiation of opportunistic, prophylactic vaccinations in 2007 and implementation of disease sentinels (unvaccinated, radiocollared foxes) for detecting an introduced pathogen in 2012. Vaccinating groups of foxes in strategic areas (e.g., surrounding ports of entry) on all islands is recommended by the Island Fox Working Group (Coonan 2012) but has not been implemented on San Clemente Island. Recent disease modeling efforts for San Clemente Island foxes found that a vaccination firewall was not more effective at stopping disease than vaccinating foxes at random (Sanchez 2012). Recognizing that the model did not consider long range movements of foxes, disclose the width of the firewall evaluated, nor evaluate the effectiveness of different firewall widths, the Island Fox Working Group recommended further assessment of firewall widths for island foxes (Coonan 2012).

Movements of infected and susceptible individuals contribute to the spread of highly contagious diseases such as rabies, and seasonal changes in activity patterns could indicate times of year in which spread of disease may be more rapid. The spatial ecology and activity patterns of island foxes have largely been inferred from published research on the Santa Cruz Island fox (U. l. santacruzae; Laughrin 1977, Fausett 1982, Crooks and Van Vuren 1996, Roemer et al. 2001b). However, California's Channel Islands vary in size, diversity of vegetation community types, diversity of species, microclimate, presence of predators, and degree of anthropogenic influences such as roads and vehicle traffic. It is reasonable to speculate that island fox spatial ecology might differ between the islands. Home ranges can be used to measure the extent of an animal's movements (Burt 1943) irrespective of how space is used within the home range boundary (Adams and Davis 1967, Samuel et al. 1985), whereas core areas identify centers of activity within a home range (Hayne 1949) that are most likely to contain principle home sites, refuges, and most dependable food sources (Kaufmann 1962).

High rates of vehicle-related mortality (Laughrin 1977) and reduced survival rates of foxes living near roads (Snow et al. 2012) have led to questions about the influence of roads on island fox movement patterns and spread of pathogens. A similar concern was expressed for the effect of railway rightsof-way on red foxes (Vulpes vulpes; Trewhella and Harris 1990). Studies support the idea that roads influence the spread of disease in humans (Eisenberg et al. 2006, Xu et al. 2014) and can facilitate the direct translocation of animal pathogens through road maintenance or construction activities (Daszak et al. 2000, Urban 2006, Pauza et al. 2010). Other studies discuss effects of roads on zoonotic disease through habitat fragmentation that disrupts predator-prey dynamics (Patz et al. 2004). Spread of chronic wasting disease is influenced by highways and rivers that serve as barriers to movement of ungulates, often with the road serving as the home range boundary (Wyckoff et al. 2012, Robinson et al. 2013). We could find no studies, however, discussing the influence of roads on spread of disease when roads are not considered movement barriers to, but conversely enhance movements of, host animals. Modeling and empirical studies have observed the spread of rabies in corridors aligning with topographical features (Timischl 1984, Moore 1999, Russell et al. 2004). Hess (1994) emphasized the influence of conservation corridors on contagious disease. We sought to investigate the spatial ecology of San Clemente Island foxes, particularly in relation to roads, to inform management and prevention of disease for this subspecies.

Our research objectives were to characterize the spatial ecology of San Clemente Island foxes by using a sample representative of the entire population, compare movement patterns of foxes with home ranges including roads to those with home ranges not including roads, and consider potential effects on spread of disease. We based hypotheses relating to the island-wide population on research findings from Santa Cruz Island foxes. For assessing the influence of roads on fox movements, we hypothesized that roads facilitate movements; therefore, movement distances would be longer and home ranges and core areas would be larger for foxes with home ranges that included roads.

\section{STUDY AREA}

Our study site comprised approximately 81 of San Clemente Island's $146 \mathrm{~km}^{2}$ (Fig. 1). We excluded portions of the island above a boundary line $300 \mathrm{~m}$ north of the airport runway $\left(2 \mathrm{~km}^{2}\right)$, below a southern boundary designated as a United States Navy (USN) training area $\left(56 \mathrm{~km}^{2}\right)$, and areas with $>25$ degree slopes on the eastern escarpment $\left(7 \mathrm{~km}^{2}\right)$ because of USN restrictions and safety concerns. San Clemente Island is the southernmost of the 8 California Channel Islands, fourth largest in the archipelago, and lies $102 \mathrm{~km}$ south of Long Beach and $126 \mathrm{~km}$ west of San Diego, California. The island is approximately $34 \mathrm{~km}$ long, $1.5-6.5 \mathrm{~km}$ wide, and is characterized by steep escarpments on the eastern slope, a gentler western slope with marine terraces, a broad central plateau running almost the entire length of the island, and deep canyons running from the upper plateau (max. elevation $=599 \mathrm{~m})$ to the shoreline on both sides of the island (Olmstead 1958, Schoenherr et al. 1999). Maritime desert scrub (59\%), grassland (17\%), maritime sage scrub (14\%), canyon shrubland-woodland (4\%), and active sand dune (1\%) comprise the island's plant communities; $2-4 \%$ of the island is disturbed or developed (USN, unpublished data).

In addition to our study species, predominant native fauna on the island include the San Clemente Island deer mouse (Peromyscus maniculatus clementis), island night lizard (Xantusia riversiana), side-blotched lizard (Uta stansburiana), California sea lion (Zalophus californianus), northern elephant seal (Mirounga angustirostris), Pacific harbor seal (Phoca vitulina richardsi), over 120 resident or migratory bird 


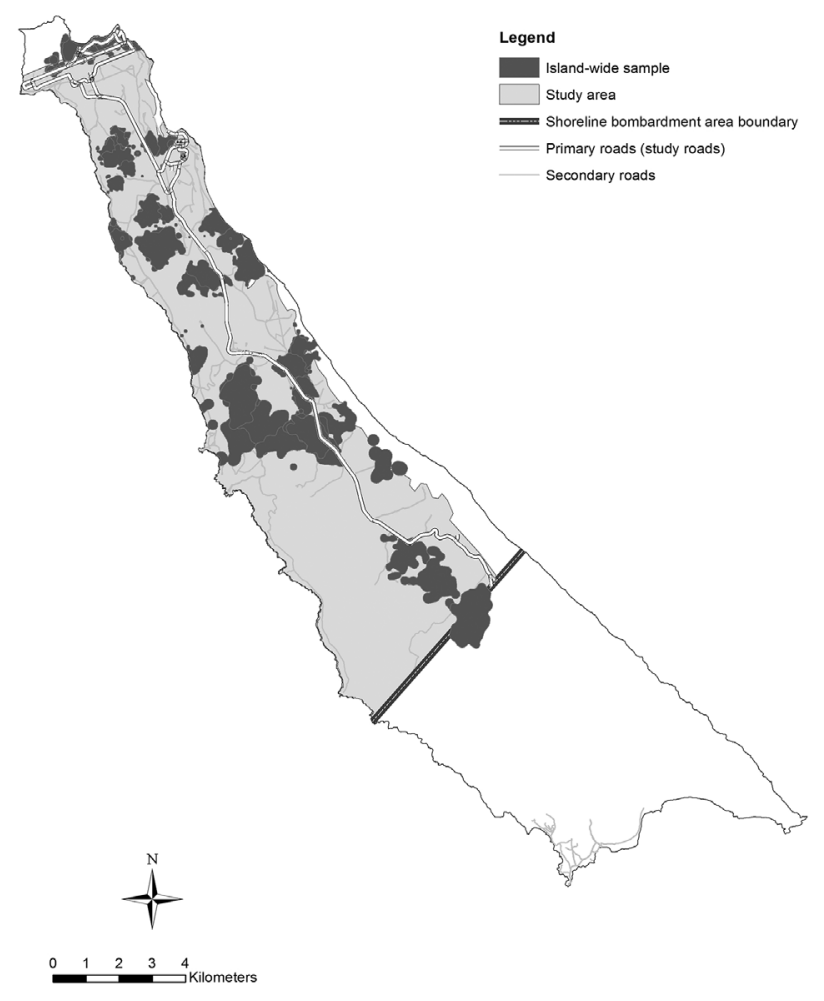

Figure 1. Study area and home ranges for our sample representing the island-wide population of San Clemente Island foxes, California, USA, 2006-2007. The island-wide sample consists of a non-road fox sample and a subset of the road fox sample.

species, and over 530 species of terrestrial invertebrates. Predominant non-native fauna include the house mouse (Mus musculus), black rat (Rattus rattus), and feral cat. San Clemente Island is host to 14 endemic plant species and 24 species of endemic animals. Federally threatened or endangered species found on the island include 3 birds, 6 plants, and 3 marine mammals; 12 primarily pelagic marine species are also associated with the island (USN 2013).

Average monthly temperatures on the island ranged from a low of $14^{\circ} \mathrm{C}$ in winter to $19^{\circ} \mathrm{C}$ in summer during $1996-2010$, with mean annual rainfall varying between $75 \mathrm{~mm}$ and $300 \mathrm{~mm}$; weather station data indicated drought conditions throughout our study from August 2006 to December 2007 (USN 2013). Our study roads consisted of primary roads (33 km) within the study area on which $\geq 70 \%$ of vehiclerelated fox mortalities occurred during 2000-2006 (Institute for Wildlife Studies, unpublished data); this included the road surrounding the airport and the main road extending the length of the island. These roads were maintained 2-lane paved or graded gravel roads $5.5-7.5 \mathrm{~m}$ wide with a maximum speed limit of $56 \mathrm{~km} /$ hour. The entire island is owned and operated by the USN and has about 500 resident military personnel and civilian contractors.

\section{METHODS}

\section{Capturing Foxes}

We used the reversed randomized quadrant-recursive raster algorithm (Theobald et al. 2007) in ArcGIS 9.2 at 30-m resolution to produce random trapping locations throughout the study area. This probability-based survey design assumed uniform density of the fox population. We live-trapped foxes using $23 \times 23 \times 66-\mathrm{cm}$ cage traps (Tomahawk Live Trap, Tomahawk, WI, USA) with either $2.54 \times 2.54-\mathrm{cm}$ mesh or $1.27 \times 2.54-\mathrm{cm}$ mesh, baited with dry cat food and a scented lure. We attached plexiglass to the inside of front doors, and installed a $46-\mathrm{cm}$-long polyethylene tube chew-bar on the inside of traps to minimize trap-related injures (Coonan et al. 2005). We covered sides and tops of traps with burlap and vegetation to provide protection from the elements. We set traps in the evening and checked them starting at sunrise.

From 18 July to 24 August 2006, we set 1 trap at each location for 2 nights and collared $\leq 2$ foxes at each location until we obtained an island-wide sample of 50 foxes. We recorded age, weight, reproductive status, and general physical condition of captured foxes. We used amount of wear on the first upper molar to age foxes (Wood 1958, Collins 1987). Similar to Crooks (1994), we identified 3 age groups consisting of young foxes (0-24 months), adults (2548 months), and old adults ( $\geq 49$ months). We used trap records $(n=33)$ from previous years when possible (Institute for Wildlife Studies, unpublished data), and cementum annulation ( $n=15$; Matson's Laboratory, Milltown, MT, USA) to improve our age estimates if foxes died during or after our study. We implanted a subcutaneous transponder chip (PIT tag; Biomark, Boise, ID, USA) between and just anterior to the scapulae. We fit foxes with $45-\mathrm{g}$ very high frequency (VHF) radio-telemetry collars (Advanced Telemetry Systems, Isanti, MI, USA) and released foxes at the site of capture; collars comprised $2.4 \%$ of average body weight of foxes. Capture, handling, collaring, and monitoring protocols were approved by Colorado State University's Institutional Animal Care and Use Committee (protocol 06-098A01) and California Department of Fish and Game.

Between mid-August and early September 2006, we obtained $\geq 30$ telemetry locations per fox stratified across the diel period to determine if home ranges for foxes in the island-wide sample appeared to include one of the study roads. Ten foxes with telemetry locations indicating movements across study roads represented our initial road sample; all other foxes comprised the non-road sample. To increase our road sample, we then divided study roads into $201.2-\mathrm{km}$ sections and set 1 trap within $10 \mathrm{~m}$ of the edge of the road for 2 nights at the midpoint of each of 12 road sections not already represented by a radio-collared fox. If we did not capture a fox, we placed successive traps at the first and third quarter-points $(0.265 \mathrm{~km}$ from the end of each road section) in randomly selected order. We radio-collared 1 fox in each of the road sections during 9-14 September and added them to the road sample but not the island-wide sample. When 3 foxes originally included in the non-road sample were later located on both sides of a study road, we reclassified them as road foxes. One fox that was captured to augment the road sample but was never observed returning to a study road was reclassified as a non-road fox (and remained excluded from the island-wide sample). We replaced foxes that died before December 2006 by capturing and radio-collaring additional foxes at random locations (for the island-wide and non-road 
samples) or in the vacated road segment (for the road sample).

\section{Radio-Telemetry}

We monitored movements of foxes from mid-August 2006 to mid-December 2007. Between 15 October 2006 and 14 October 2007, we radio-located foxes every 2 hours during 1 8-hour period (0000-0759, 0800-1559, 1600-2359 hours) that rotated every 1-1.5 weeks. We tracked foxes less frequently during the 2 months before and after this period to evaluate dispersal. We monitored radio-signals with receivers (Advanced Telemetry Systems, Isanti, MI) connected to vehicle-mounted, stacked-arrays of 2 6-element antennae that used null-peak systems. We located foxes from 1 vehicle and obtained directional azimuths in succession from 3 locations. We minimized locational error and elapsed time between telemetry bearings by obtaining bearings $>20^{\circ}$ and $<160^{\circ}$ apart and striving to obtain consecutive bearings $\leq 5$ minutes apart. We discarded locations with sets of triangulations $>20$ minutes apart (Crooks and Van Vuren 1996).

To minimize error from radio-tracking equipment, we tested equipment monthly and corrected our data by the average difference between antenna bearing and true bearing to a reference radio-collar $100-1,000 \mathrm{~m}$ distant $(\bar{x}=586 \mathrm{~m})$. Our average bearing error for the 2 tracking units equated to $12.7 \mathrm{~m}$ (unit 1) or $7.8 \mathrm{~m}$ (unit 2) at $586 \mathrm{~m}$. We averaged the differences over the study period for each of the 2 vehiclemounted tracking units $\left(n_{1}=45, \bar{x}_{1}=1.24^{\circ}, \mathrm{SD}_{1}=1.55\right.$; $\left.n_{2}=38, \bar{x}_{2}=-0.76^{\circ}, \mathrm{SD}_{2}=1.56\right)$ and used a slightly more conservative estimate $(\mathrm{SD}=2)$ to represent bearing error when estimating Universal Transverse Mercator (UTM) locations of foxes. We corrected all data by the average magnetic declination $\left(12.817^{\circ}\right)$ during our study period.

\section{Spatial Distribution and Movements}

Home ranges, core areas, and site fidelity.-We used Location of a Signal software (Ecological Software Solutions, Urnäsch, Switzerland) to estimate UTM locations of foxes and set objective thresholds for including data (Resnik 2012). We estimated home ranges using the animal movement SA extension (Hooge and Eichenlaub 2000) in ArcView 3.3 (Environmental Systems Research Institute, Redlands, CA, USA), the kernel density estimator (Silverman 1986; Worton 1987, 1989), fixed smoothing technique (Seaman and Powell 1996), and least-squares cross-validation (LSCV) for bandwidth selection (Worton 1989, Seaman et al. 1999, Powell 2000). We estimated home ranges using the 95\% isopleth (White and Garrott 1990, Laver and Kelly 2008) of the utilization distribution (UD; Van Winkle 1975). We defined an excursion as a temporary movement $\geq 1 \mathrm{~km}$ from the nearest location within the $95 \%$ UD isopleth calculated with all excursions included (Adams et al. 2008, Skuldt et al. 2008). We excluded excursions from UD calculations because they can greatly influence home range estimates (Dunn and Gipson 1977, Kernohan et al. 2001) and bias them to include largely unused areas (Kenward 2001). We calculated topographic surface area from flat, planimetric area using a $10-\mathrm{m}$ digital elevation model to accurately depict land area used and resources available within a home range (Powell and Mitchell 1998, Jenness 2004, Greenberg and McClintock 2008). We used 95\% UD estimates for all statistical analyses; we calculated 95\% minimum convex polygons to compare our home range and core area estimates to those of other island fox subspecies.

We produced representative home ranges by using only foxes for which $\geq 80 \%$ of attempts to radio-locate the fox were successful. For 2 foxes that used 2 distinct (i.e., split) home ranges throughout the monitoring period, we estimated separate UDs then combined them into a cumulative home range. We clipped home ranges at the shoreline when they overlapped the ocean. We defined areas of concentrated use (i.e., core areas) empirically rather than with an arbitrary value (Powell 2000, Burdett et al. 2007) by using the inflection point $(\bar{x}=67 \pm 2[\mathrm{SE}] \%$, range $=50-$ $85 \%)$ on a plot of area against fixed-kernel UD isopleths (Harris et al. 1990, Bingham and Noon 1997).

We used observation-area curves (Cain 1938, Odum and Kuenzler 1955) to estimate annual home ranges and core areas for foxes that were monitored during all 3 seasons (defined below) and had $\geq 90$ locations. We estimated seasonal home ranges and seasonal core areas for foxes with $\geq 30$ observations in a given season (Seaman et al. 1999, Kernohan et al. 2001) and located $>66 \%$ of the season. To avoid confounding comparisons between the road and nonroad samples, we used PROC TTEST (SAS Institute, Cary, $\mathrm{NC}$, USA) to assess whether error ellipses, number of successful radio-locations used to estimate the 95\% UD, probability of successfully obtaining a radio-telemetry location, or least-squares cross-validation (LSCV) bandwidth differed $(P<0.05)$ between samples. We also considered the possibility of correlation between number of successful radio-locations, percent of successful radiolocations, probability of LSCV bandwidth, and 95\% UD $(P<0.05$; SAS PROC CORR).

Following Roemer et al. (2001b) and Kitchen et al. (2005), we identified biologically relevant seasons by using the reproductive chronology of San Clemente Island foxes (Resnik and Andelt 2012): breeding and gestation (breeding; 15 Oct 2006-14 Feb 2007), parturition and pup-dependence (pup-dependence; $15 \mathrm{Feb}-14$ June 2007), and pup-independence and dispersal (pup-independence; 15 Jun-14 Oct 2007). We estimated site fidelity among seasons for individual foxes by dividing the area of intersection for 2 seasonal home ranges (or core areas) by the union of the home ranges (or core areas; Millspaugh et al. 2004). We used proportion of overlap (intersection divided by union) among all seasons to represent overall site fidelity for the year.

Movement patterns and dispersal.-We estimated movement distances of individual foxes by comparing UTM coordinates from consecutive radio-locations obtained 2 hours apart $( \pm 15 \mathrm{~min})$. This was inherently a conservative estimate and represented the linear distance moved between 2 points. In cases where straight-line distances overlapped water, we replaced the length of the overlapping line segment with the length of the adjacent shoreline. We then calculated 
surface distance from linear distance using a 10-m digital elevation model (Jenness 2004). We used sunrise, sunset, and astronomical twilight (the time at which the sun is 18 geometric degrees below the horizon and scattered light from the sun is less than that from starlight or other natural sources; U.S. Naval Observatory 2014) to characterize the diel period. We defined dawn as the time during which the sun is in transit from 18 degrees below to 18 degrees above the horizon; and vice versa for dusk. We used separate variables to partition the diel period into 4 segments (dawn, day, dusk, night); 3 segments (day, night, crepuscular [dawn and dusk combined]); and 2 segments (day, night [using simple sunrise and sunset times]).

We defined dispersal as 1-way movement of a fox from an area that had been occupied for a period of time (White and Garrott 1990). We distinguished dispersal from a shift in seasonal home ranges by considering absence of overlap between the first (breeding) and last (pup-independence) of 3 consecutive seasons in our study as evidence of possible dispersal (Storm et al. 1976).

\section{Data Analyses}

We used multiple regression analyses (SAS PROC MIXED) to compare size and site fidelity (i.e., overlap) of home ranges and core areas in candidate models; comparisons across all 3 seasons considered individual foxes as repeated measures. We evaluated 4 variables in single-variable a priori models: sex (male, female), age (young, adult, old adult), season (breeding, pup-dependence, pup-independence), and road (road or non-road sample). Based on biological interest and results from a priori model analyses, we considered post hoc models that evaluated the interaction between sex and season, or road and season. We used multiple regression in SAS PROC GLM to compare movement distances in candidate models. We treated foxes as a random effect in analyses that evaluated 5 variables in a priori models that were either single-variable (sex, season, age, road, diel_DN [day, night], diel_DNC [day, night, crepuscular], or diel_DDDN [dawn, day, dusk, night]) or included interaction terms (season and diel_DNC, or season and diel_DDDN). Based on results from a priori model analyses, we considered 1 post hoc model that evaluated the interaction between road and diel_DDDN.

We log-transformed response variables (e.g., home range size, site fidelity, and movement distance) prior to analyses to better meet the assumptions of normality and homogeneity of variances for multiple regression. We used an information-theoretic approach with Akaike's Information Criterion corrected for small sample sizes $\left(\mathrm{AIC}_{c}\right)$ and deviation of $\mathrm{AIC}_{c}$ values $\left(\Delta \mathrm{AIC}_{c}\right)$ from the lowest value in the model suite to identify models with strong support $\left(\Delta \mathrm{AIC}_{c}<2\right)$, weak support $\left(\Delta \mathrm{AIC}_{c}=2-10\right)$, and no support $\left(\Delta \mathrm{AIC}_{c}>10\right)$ from the data (Burnham and Anderson 2002). For the top model in each analysis, we evaluated the relevant fixed categorical effects by computing mean differences in least squares means for all pairwise comparisons and determining whether the 95\% confidence interval overlapped zero. For analyses involving the road and non-road samples, which are binary categories, we provided mean differences in least squares means and confidence intervals for only the variable of interest (road) or interactions containing that variable.

We assumed straight-line movement paths and determined Euclidian distance from the middle point of each 2-hour road fox movement path to the nearest study road (i.e., proximity of a road fox movement to a road). We then log transformed the length of the straight-line movement path and regressed it against proximity to the road (using SAS PROC GLM) to estimate the relationship between the length of 2-hour movement paths (the dependent variable) and proximity of road foxes to a study road (the predictor variable). We performed regressions for each fox, estimated the slope of the regression line for each fox, and averaged the slopes (over all road foxes, by sex and then by season). We computed variances of the averaged slopes using the delta method (Seber 1982) and used them to construct 95\% confidence intervals. We performed back transformation of straight-line movement lengths from the log scale to predict road fox movement lengths at distances of $1 \mathrm{~m}$ and $220 \mathrm{~m}$ (the average proximity of all road fox movements) from the study road. We used histograms to examine the frequency with which road fox movements occur at various proximities to the road.

\section{RESULTS}

We captured and radio-collared 65 foxes $(28$ males, 37 females); 9 foxes died too early in the study to include in our analyses, and we could not adequately monitor 11 foxes because of access restrictions. Thirty-seven of the remaining foxes $(>82 \%)$ met our standards for inclusion in annual and seasonal home range and core area analyses (Tables 1 and 2). Fourteen males and 23 females were distributed as 13 young foxes, 16 adults, and 8 old adults across the 3 study samples (island-wide foxes, road foxes, and non-road foxes). Male foxes $(\bar{x}=2.0 \mathrm{~kg})$ weighed more than females $(\bar{x}=1.8 \mathrm{~kg} ; \beta=0.18,95 \%$ $\mathrm{CI}=0.03-0.33)$. From 18 August 2006-10 December 2007, we recorded approximately 8,900 locations of foxes ( $>95 \%$ triangulations) and excluded $<4 \%$ for exceeding error thresholds. We observed 16 unique excursions $(\bar{x}=2.37$ \pm 0.31 , range $=1.04-5.28 \mathrm{~km}$ ) for 6 foxes ( 3 males, 3 females) among the seasons (breeding $=1$, pup-dependence $=7$, pupindependence $=8$ ) and removed them from final home range estimates. Two road foxes accounted for 5 of the excursions $(\bar{x}=2.84, \mathrm{SE}=0.67$, range $=1.66-5.28)$ and 4 non-road foxes accounted for the other $11(\bar{x}=2.03, \mathrm{SE}=0.35$, range $=1.04-4.97 \mathrm{~km})$. The farthest excursion we recorded $(5.28 \mathrm{~km})$ represents the long-distance movement potential for the San Clemente Island fox during our study.

We calculated annual and seasonal home ranges for the random sample using an average of 151 locations $(\mathrm{SE}=4$, range $=113-194)$ and 50 locations $(\mathrm{SE}=1$, range $=30-71)$, respectively. We found evidence that the road sample had smaller error ellipses $\left(\bar{x}=3,232 \mathrm{~m}^{2}, \mathrm{SE}=84\right)$ than the nonroad sample $\left(\bar{x}=6,043 \mathrm{~m}^{2}, \mathrm{SE}=151 ; P<0.001\right)$ but larger bandwidths $(\bar{x}=94, \mathrm{SE}=6)$ than the non-road sample $(\bar{x}=68, \mathrm{SE}=4 ; P<0.001)$. More locations were obtained on $\operatorname{road}$ foxes $(\bar{x}=153, \mathrm{SE}=10)$ than non-road foxes 
Table 1. Topographic fixed-kernel ${ }^{\mathrm{a}}$ annual and seasonal home ranges $\left(\mathrm{km}^{2} ; 95 \%\right.$ isopleth) and core areas ( $\mathrm{km}^{2}$; variable isopleths) by sex for an island-wide sample of San Clemente Island foxes, California, USA, 2006-2007.

\begin{tabular}{|c|c|c|c|c|}
\hline & \multirow[b]{2}{*}{ Annual } & \multicolumn{3}{|c|}{ Seasonal } \\
\hline & & Breeding & Pup-dependence & Pup-independence \\
\hline \multicolumn{5}{|c|}{ Home range } \\
\hline \multicolumn{5}{|c|}{ Total $(n=29)$} \\
\hline $\bar{x}$ & 0.75 & 0.66 & 0.68 & 0.76 \\
\hline $\mathrm{SE}$ & 0.09 & 0.10 & 0.11 & 0.07 \\
\hline Range & $0.19-2.69$ & $0.17-2.85$ & $0.15-3.14$ & $0.21-1.66$ \\
\hline \multicolumn{5}{|c|}{ Male $(n=12)$} \\
\hline $\bar{x}$ & 0.69 & 0.57 & 0.63 & 0.71 \\
\hline $\mathrm{SE}$ & 0.13 & 0.11 & 0.10 & 0.15 \\
\hline \multicolumn{5}{|c|}{ Female $(n=17)$} \\
\hline $\bar{x}$ & 0.79 & 0.72 & 0.71 & 0.79 \\
\hline SE & 0.14 & 0.15 & 0.17 & 0.07 \\
\hline \multicolumn{5}{|l|}{ Core area } \\
\hline \multicolumn{5}{|c|}{ Total $(n=29)$} \\
\hline $\bar{x}$ & 0.19 & 0.15 & 0.14 & 0.16 \\
\hline SE & 0.03 & 0.02 & 0.02 & 0.02 \\
\hline Range & $0.05-0.64$ & $0.04-0.65$ & $0.03-0.39$ & $0.04-0.39$ \\
\hline \multicolumn{5}{|c|}{ Male $(n=12)$} \\
\hline $\bar{x}$ & 0.19 & 0.15 & 0.14 & 0.16 \\
\hline $\mathrm{SE}$ & 0.05 & 0.03 & 0.02 & 0.04 \\
\hline \multicolumn{5}{|c|}{ Female $(n=17)$} \\
\hline $\bar{x}$ & 0.19 & 0.16 & 0.13 & 0.16 \\
\hline SE & 0.03 & 0.04 & 0.02 & 0.02 \\
\hline
\end{tabular}

a 95\% minimum convex polygon estimates are reported in Resnik (2012).

$(\bar{x}=132, \mathrm{SE}=3 ; P=0.049)$ and percent of successful radiolocations was higher for road foxes $(\bar{x}=0.96, \mathrm{SE}=0.01)$ than non-road foxes $(\bar{x}=0.92, \mathrm{SE}=0.01 ; P=0.028)$. We found weak evidence that number of locations was correlated with size of bandwidth $(\rho=-0.29, P=0.067)$ and size of 95\% fixed-kernel UD $(\rho=-0.030, P=0.08)$.

\section{Sizes of Home Ranges and Core Areas}

Annual home range and core area sizes for our island-wide sample did not differ by sex or age (Appendix A, Table A). However, seasonal home range sizes varied by season and were $12 \%$ and $15 \%$ larger, respectively, during pupindependence than during pup-dependence and breeding (Table 1). Home range sizes did not differ between breeding and pup-dependence and core area sizes did not differ between seasons. Post hoc models that considered season + sex, or season $+\operatorname{sex}+($ season $\times \operatorname{sex})$, as predictors for seasonal home range and core areas did not have smaller $\mathrm{AIC}_{c}$ values than a priori models (Appendix A, Table A).

Annual home ranges were $78 \%$ larger and annual core areas were $73 \%$ larger for road foxes than for non-road foxes (Appendix A, Table B). Among the seasons, home ranges were

Table 2. Topographic fixed-kernel ${ }^{\mathrm{a}}$ annual and seasonal home ranges $\left(\mathrm{km}^{2} ; 95 \%\right.$ isopleths) and core areas $\left(\mathrm{km}^{2}\right.$; variable isopleths) for road and non-road samples ${ }^{\mathrm{b}}$ of San Clemente Island foxes, California, USA, 2006-2007.

\begin{tabular}{|c|c|c|c|c|}
\hline & \multirow[b]{2}{*}{ Annual } & \multicolumn{3}{|c|}{ Seasonal } \\
\hline & & Breeding & Pup-dependence & Pup-independence \\
\hline \multicolumn{5}{|l|}{ Home range } \\
\hline \multicolumn{5}{|c|}{ Road $(n=18)$} \\
\hline $\bar{x}$ & 1.07 & 1.07 & 0.82 & 0.95 \\
\hline $\mathrm{SE}$ & 0.15 & 0.17 & 0.16 & 0.09 \\
\hline Range & $0.55-2.69$ & $0.44-2.85$ & $0.19-3.14$ & $0.42-1.65$ \\
\hline \multicolumn{5}{|c|}{ Non-road $(n=19)$} \\
\hline $\bar{x}$ & 0.60 & 0.51 & 0.60 & 0.60 \\
\hline SE & 0.09 & 0.07 & 0.08 & 0.08 \\
\hline Range & $0.19-1.67$ & $0.17-1.27$ & $0.15-1.58$ & $0.21-1.66$ \\
\hline \multicolumn{5}{|l|}{ Core area } \\
\hline \multicolumn{5}{|c|}{ Road $(n=18)$} \\
\hline $\bar{x}$ & 0.26 & 0.24 & 0.16 & 0.20 \\
\hline SE & 0.02 & 0.04 & 0.03 & 0.02 \\
\hline Range & $0.11-0.64$ & $0.04-0.65$ & $0.04-0.38$ & $0.03-0.38$ \\
\hline \multicolumn{5}{|c|}{ Non-road $(n=19)$} \\
\hline $\bar{x}$ & 0.15 & 0.12 & 0.13 & 0.13 \\
\hline SE & 0.04 & 0.02 & 0.02 & 0.02 \\
\hline Range & $0.05-0.46$ & $0.04-0.34$ & $0.03-0.39$ & $0.04-0.39$ \\
\hline
\end{tabular}

a 95\% minimum convex polygon estimates are reported in Resnik (2012).

${ }^{\mathrm{b}}$ Foxes had a home range either overlapping (road sample) or not overlapping (non-road sample) a road. 
between 0.37 and 1.1 times larger and core areas were between 0.23 and 1.0 times larger for road foxes than non-road foxes (Table 2). A post hoc model that considered road + season +( road $\times$ season) as predictors for seasonal home range areas had a smaller $\mathrm{AIC}_{c}$ value than a priori models (Appendix A, Table B). Home ranges for road foxes compared to non-road foxes were 1.1 times larger during the breeding season and $58 \%$ larger during the pup-independence season but did not differ during the pup-dependence season.

Site fidelity for the island-wide sample varied among sexes for seasonal home ranges but not for seasonal core areas (Appendix A, Table C). Spatial overlap among all seasonal home ranges was larger for males in the general population than for females (Table 3). Amount of home range overlap among seasons did not differ between road and non-road foxes. However, top models included road as a predictor of site fidelity among seasonal core areas (Appendix A, Table C).

\section{Movement Distances and Dispersal}

Movement distances for discrete 2-hour intervals for the island-wide sample were shorter during the day than during dawn, dusk, or night (Appendix A, Table D). For our comparison of road and non-road samples, the minimum $\mathrm{AIC}_{c}$ model included road, diel_DDDN, and their interaction term as predictors for movement distances. Road foxes moved 33\% farther during 2-hour intervals than non-road foxes (Table 4). However, road foxes moved greater distances than non-road foxes only during dusk. We recorded temporary forays outside of home range boundaries, but we detected no dispersal activity in the island-wide, road, and non-road samples.
For all models and variables, the $95 \%$ confidence intervals did not cover zero for the averaged slopes of 2-hour road fox movement path lengths and proximity of the movement paths to a road (Table 5). This suggests that straight line movements were longer near roads than when farther from roads. Frequency of movements at given distances from the road did not differ appreciably between seasons (Fig. 2) or between sexes (Fig. 3). Over a third of road fox movements (as determined by the midpoint of 2-hour straight-line movement paths) were found within $100 \mathrm{~m}$ of the road, roughly $50 \%$ within $150 \mathrm{~m}$ of the road, $75 \%$ within $300 \mathrm{~m}$, and over $90 \%$ within $500 \mathrm{~m}$.

\section{DISCUSSION}

Larger home ranges and core areas for road foxes, greater average movement distances of road versus non-road foxes, and longer movements near roads suggest that primary roads may serve as transmission corridors for pathogens in the fox population on San Clemente Island. Connectivity among populations has been implicated in enhancing spread of disease in multiple wildlife epizootics (Hess 1996, Marquardt 2005, Cleaveland et al. 2008, Woodroffe et al. 2012). An inadvertent consequence of road corridors could be facilitation of spread of disease as seen with other diseases and systems (Marquardt 2005, Eisenberg et al. 2006, Xu et al. 2014). Incorporating topography and landscape features is recommended when developing wildlife disease control tactics (Timischl 1984, Moore 1999, Rosatte et al. 2010). The Island Fox Working Group recommends that vaccination strategies should consider island geography (Coonan 2012). We recommend that a vaccination strategy

Table 3. Site fidelity (i.e., proportion of overlap) among all and between paired seasonal fixed-kernel home ranges $\left(\mathrm{km}^{2} ; 95 \%\right.$ isopleth) and core areas $\left(\mathrm{km}^{2}\right.$; variable isopleths) for an island-wide sample of San Clemente Island foxes, California, USA, 2006-2007.

\begin{tabular}{|c|c|c|c|c|}
\hline & \multirow[b]{2}{*}{ All seasons } & \multicolumn{3}{|c|}{ Paired seasons } \\
\hline & & Breeding and pup-dependence ${ }^{a}$ & Pup-dependence and pup-independence ${ }^{a}$ & Pup-independence and breeding ${ }^{b}$ \\
\hline \multicolumn{5}{|l|}{ Home range } \\
\hline \multicolumn{5}{|c|}{ Total $(n=29)$} \\
\hline $\bar{x}$ & 0.32 & 0.52 & 0.47 & 0.45 \\
\hline SE & 0.02 & 0.02 & 0.02 & 0.02 \\
\hline Range & $0.18-0.50$ & $0.30-0.72$ & $0.22-0.69$ & $0.20-0.67$ \\
\hline \multicolumn{5}{|c|}{ Male $(n=12)$} \\
\hline $\bar{x}$ & 0.38 & 0.56 & 0.52 & 0.50 \\
\hline $\mathrm{SE}$ & 0.03 & 0.04 & 0.03 & 0.04 \\
\hline \multicolumn{5}{|c|}{ Female $(n=17)$} \\
\hline $\bar{x}$ & 0.28 & 0.49 & 0.43 & 0.41 \\
\hline $\mathrm{SE}$ & 0.02 & 0.03 & 0.03 & 0.02 \\
\hline \multicolumn{5}{|l|}{ Core area } \\
\hline \multicolumn{5}{|c|}{ Total $(n=29)$} \\
\hline $\bar{x}$ & 0.12 & 0.31 & 0.24 & 0.27 \\
\hline SE & 0.02 & 0.03 & 0.03 & 0.03 \\
\hline Range & $0.00-0.34$ & $0.05-0.54$ & $0.00-0.46$ & $0.04-0.77$ \\
\hline \multicolumn{5}{|c|}{ Male $(n=12)$} \\
\hline $\bar{x}$ & 0.11 & 0.29 & 0.25 & 0.24 \\
\hline SE & 0.01 & 0.03 & 0.03 & 0.03 \\
\hline \multicolumn{5}{|c|}{ Female $(n=17)$} \\
\hline $\bar{x}$ & 0.12 & 0.31 & 0.23 & 0.29 \\
\hline SE & 0.03 & 0.04 & 0.04 & 0.04 \\
\hline
\end{tabular}

${ }^{a}$ Consecutive seasons

b Non-consecutive seasons. 
Table 4. Movement distances $(\mathrm{km})$ for discrete 2-hour intervals by diel period ${ }^{\mathrm{a}}$ for island-wide, road, and non-road samples ${ }^{\mathrm{b}}$ of San Clemente Island foxes, California, USA, 2006-2007.

\begin{tabular}{|c|c|c|c|c|c|}
\hline \multirow[b]{2}{*}{ Sample } & \multicolumn{5}{|c|}{ Diel period } \\
\hline & Overall & Dawn & Day & Dusk & Night \\
\hline \multicolumn{6}{|c|}{ Island-wide ( $n=29$ foxes) } \\
\hline$n$ (movements) & 2,863 & 493 & 983 & 496 & 891 \\
\hline $\bar{x}$ & 0.27 & 0.31 & 0.14 & 0.34 & 0.36 \\
\hline $\mathrm{SE}$ & 0.28 & 0.28 & 0.20 & 0.31 & 0.30 \\
\hline Range & $0-3.22$ & $0-2.12$ & $0-1.49$ & $0-1.9$ & $0-3.2$ \\
\hline \multicolumn{6}{|l|}{ Road ( $n=18$ foxes) } \\
\hline$n$ (movements) & 2,183 & 317 & 751 & 446 & 669 \\
\hline $\bar{x}$ & 0.32 & 0.38 & 0.15 & 0.45 & 0.40 \\
\hline SE & 0.35 & 0.41 & 0.22 & 0.40 & 0.34 \\
\hline Range & $0-4.08$ & $0-3.67$ & $0-1.49$ & $0-4.08$ & $0-3.22$ \\
\hline \multicolumn{6}{|c|}{ Non-road ( $n=19$ foxes) } \\
\hline$n$ (movements) & 1,719 & 324 & 598 & 259 & 538 \\
\hline $\bar{x}$ & 0.24 & 0.27 & 0.13 & 0.24 & 0.33 \\
\hline $\mathrm{SE}$ & 0.23 & 0.23 & 0.18 & 0.23 & 0.24 \\
\hline Range & $0-1.33$ & $0-1.21$ & $0-1.06$ & $0-1.14$ & $0-1.33$ \\
\hline
\end{tabular}

${ }^{a}$ The 24-hour diel period is divided into 4 segments: dawn, day, dusk, and night.

${ }^{\mathrm{b}}$ Foxes had a home range either overlapping (road sample) or not overlapping (non-road sample) a study road. The island-wide sample consisted of all nonroad foxes and a subset of road foxes.

on San Clemente Island should also consider the location of roads. In particular, disease modeling efforts should evaluate using wider vaccination firewalls and vaccinating foxes that live near roads and those living away from roads in different proportions.

Island foxes occur in some of the highest population densities recorded for any canid (Roemer et al. 2001b) but it is unknown whether population density or rates of contact differ between the road and non-road sub-populations on San Clemente Island. Snow and Andelt (2013) reported that capture success for foxes was highest near roads on San Clemente Island, suggesting perhaps a higher density of foxes near roads. Increased contact among species subpopulations has been reported to increase the prevalence, incidence, and rate of spread of canine distemper and rabies in the overall population (Cleaveland et al. 2008, Woodroffe et al. 2012). In our study, we did not find evidence of dispersal and foxes exhibited a low excursion rate. We

Table 5. Results for our regressions of the log-transformed length of the straight-line movement path (dependent variable) against proximity of the movement path to the road (predictor variable) for road foxes on San Clemente Island, California, USA, 2006-2007. Examples are provided for predicted movement lengths at $1 \mathrm{~m}$ and $220 \mathrm{~m}$ (the average proximity of all road fox movements) from the study road.

\begin{tabular}{|c|c|c|c|c|c|}
\hline \multirow[b]{2}{*}{$\begin{array}{l}\text { Models and } \\
\text { variables }\end{array}$} & \multirow[b]{2}{*}{$\begin{array}{c}\text { Average } \\
\text { slope }\end{array}$} & \multicolumn{2}{|c|}{$95 \% \mathrm{CI}$} & \multicolumn{2}{|c|}{$\begin{array}{l}\text { Movement } \\
\text { length }(m)^{a}\end{array}$} \\
\hline & & Lower & Upper & $1 \mathrm{~m}$ & $220 \mathrm{~m}$ \\
\hline All road foxes & -0.002 & -0.003 & -0.002 & 208 & 125 \\
\hline \multicolumn{6}{|l|}{ Sex } \\
\hline Female & -0.003 & -0.004 & -0.002 & 229 & 126 \\
\hline Male & -0.002 & -0.003 & -0.001 & 171 & 121 \\
\hline \multicolumn{6}{|l|}{ Season } \\
\hline Breeding & -0.002 & -0.003 & -0.001 & 235 & 145 \\
\hline Pup-dependence & -0.002 & -0.003 & -0.001 & 197 & 126 \\
\hline Pup-independence & -0.003 & -0.004 & -0.002 & 221 & 118 \\
\hline
\end{tabular}

${ }^{a}$ Predicted movement length $(\mathrm{m})$ based on road proximity. surmise that disease would thus spread farther and faster in foxes near roads simply because road foxes move farther and faster than non-road foxes.

Many mammal species use roads, railroads, and right-ofways, but the function of roads as movement corridors for wildlife is not well understood (Trewhella and Harris 1990, Huijser and Clevenger 2006). Roads, however, are inherently corridors for human movement. As a zoonotic disease, management of rabies in wildlife has an important public health component. Spatial topology of roads in relation to areas of high fox and high human population densities is therefore important to consider. Evidenced by the high incidence of vehicle strikes with foxes (Snow et al. 2012), there is increased likelihood of human-fox contact on or near San Clemente Island roads. Vaccination of foxes around areas of human concentration is already part of the Island Fox Working Group protocol (Coonan 2012); we suggest roads be considered similarly. For example, the high mortality rate of road foxes on San Clemente Island (Snow et al. 2012) presents a challenge for preventing spread of disease because high population turnover can result in variable success of vaccination efforts (Hampson et al. 2009).

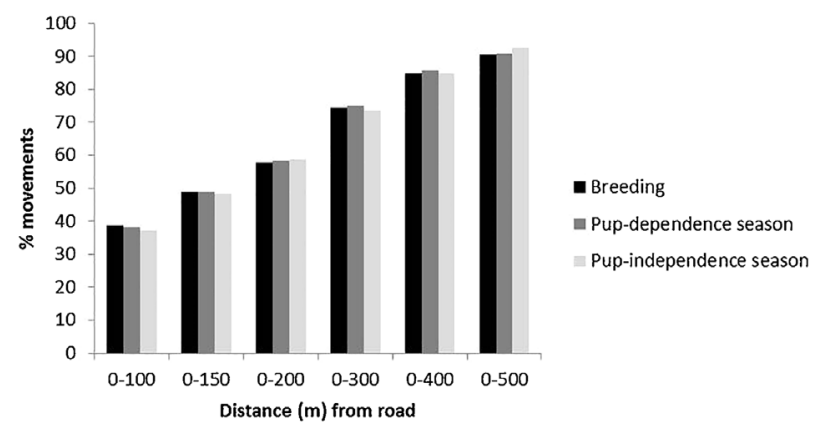

Figure 2. Percent of total road fox movements at given distances (m) from the road did not differ appreciably between seasons on San Clemente Island, California, USA, 2006-2007. 


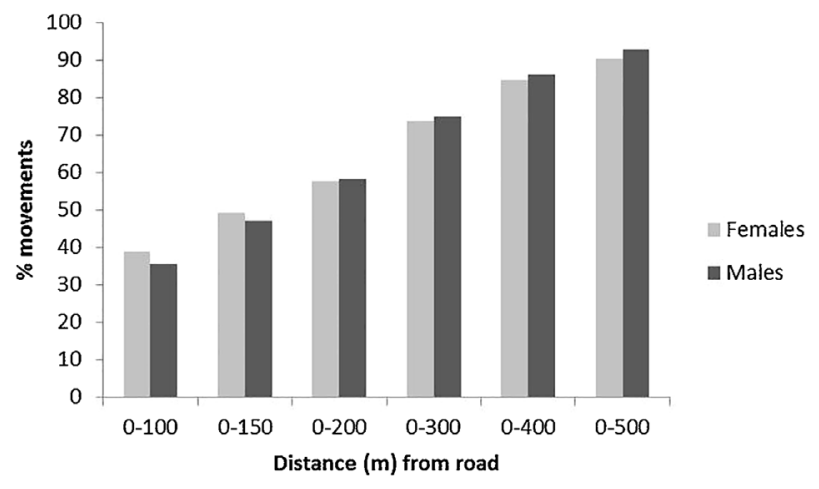

Figure 3. Percent of total road fox movements at given distances $(\mathrm{m})$ from the road did not differ appreciably between sexes on San Clemente Island, California, USA, 2006-2007.

Based on the longest fox excursion we recorded, a vaccination firewall that is a minimum of $5.3 \mathrm{~km}$ wide may be able to contain an outbreak of rabies or canine distemper in the fox population on San Clemente Island. Effectiveness of these firewalls is dependent on their width relative to an animal's long-range movements. For instance, a rabies vaccination barrier was successful only after the initial $16 \mathrm{~km}$-wide zone was expanded to $40 \mathrm{~km}$ to account for long-distance movement potential of raccoons (Procyon lotor) in the area (Smith et al. 1999). In another instance, a rabies control program used a vaccination zone $18-25 \mathrm{~km}$ wide that was intended to encompass only $90 \%$ of raccoon movements (Rosatte et al. 2001). Potential cost effectiveness and acceptable levels of risk are management considerations that disease modeling can help inform when assessing the optimal width of a vaccination firewall on San Clemente Island.

In addition to recommendations for vaccinating island foxes near ports of entry (Coonan 2012), we recommend managers consider the topology of roads when determining placement and configuration of a vaccination firewall outside ports of entry. Given the elongate shape of San Clemente Island, the most effective configuration for this firewall may be one that is perpendicular to the long axis of the island, deliberately intersects primary roads, and is wider (or foxes are vaccinated in higher proportion) where roads and the firewall intersect. Our summary of the frequency of road fox movements at various distance intervals from the road can be used as a guide for managers wishing to target foxes near roads for vaccination (Figs. 2 and 3). We found that 50\% of road fox movements occurred within $150 \mathrm{~m}$ of roads during any season. Thus, if 15 traps were available, then on average it would be more efficient (in terms of trap-nights per capture) to place 5 traps within $150 \mathrm{~m}$ of the road at each of 3 widely spaced locations (so as to intersect 3 distinct road fox territories) than to place 15 traps within $450 \mathrm{~m}$ of the road at a single location (intersecting only 1 road fox territory). This would therefore be an efficient means of capturing (and vaccinating) road foxes more quickly.

Annual home range size estimates for our island-wide sample were $0.36-1.23$ times larger and core area estimates were 2.17 times larger than estimates generalized from island foxes on Santa Cruz Island (Crooks and Van Vuren 1996, Roemer et al. 2001b). Although this may be partly due to different methodologies, it may also indicate that substantive differences exist in spatial ecology between island fox subspecies. For example, golden eagles are predators of foxes on Santa Cruz Island, influence their behavior, and were present during all home range studies. Golden eagle predation was suggested as a possible cause of low dispersal rates and distances for adult and juvenile island foxes (Roemer et al. 2001b); however, our findings suggest that dispersal is limited for island foxes even when predators are absent.

Home range sizes of San Clemente Island foxes varied seasonally, agreeing with an earlier study that reported starting in the fall island fox adults spend less time with their pups and range more widely (Fausett 1982). During the pup-independence and breeding seasons, foxes with home ranges that included roads also ranged more widely than foxes with home ranges that did not include roads. Although our results indicate that a vaccination campaign might be most effective during the pup-dependence season when fox movements are most limited, trapping is not permitted during this season because it might separate young pups from their parents. Population monitoring of San Clemente Island foxes has typically occurred JuneAugust (Rubin et al. 2007). Our finding that home range size fluctuates seasonally suggests that estimates of population size and density would be most accurate when using home range estimates for the appropriate season rather than an annual estimate.

We found less annual site fidelity for San Clemente Island foxes than expected based on findings that foxes on Santa Cruz Island were territorial (Roemer et al. 2001b) and maintained similar home range sizes year-round (Crooks and Van Vuren 1996). We speculate that low reproductive success during 2007 (Resnik and Andelt 2012) could have produced less site fidelity, and perhaps a smaller difference in seasonal home range and core area size between sexes, than might occur during years of higher reproductive success. Our findings that males had more home range fidelity than females supports previous findings that male and female island foxes care for young (Garcelon et al. 1999), but only male island foxes form and maintain territories (Roemer et al. 2001b).

We originally expected that home ranges encompassing roads would be larger because foxes might use them as movement corridors. However, Snow et al. (2012) used the same foxes and data as our study and did not locate foxes on or within $100 \mathrm{~m}$ of roads more than expected at random. We also expected that if foxes preferentially used roads, spatial orientation of their home ranges would be elongated along roads within their home range. However, road fox home ranges were neither noticeably different in shape from those of non-road foxes (Fig. 4) nor did they appear to be elongate along study roads (Fig. 5). Nevertheless, our data did indicate that foxes moved longer distances when closer versus farther from roads (Table 5). Perhaps foxes do not preferentially select roads for movements but are simply able to move faster when 


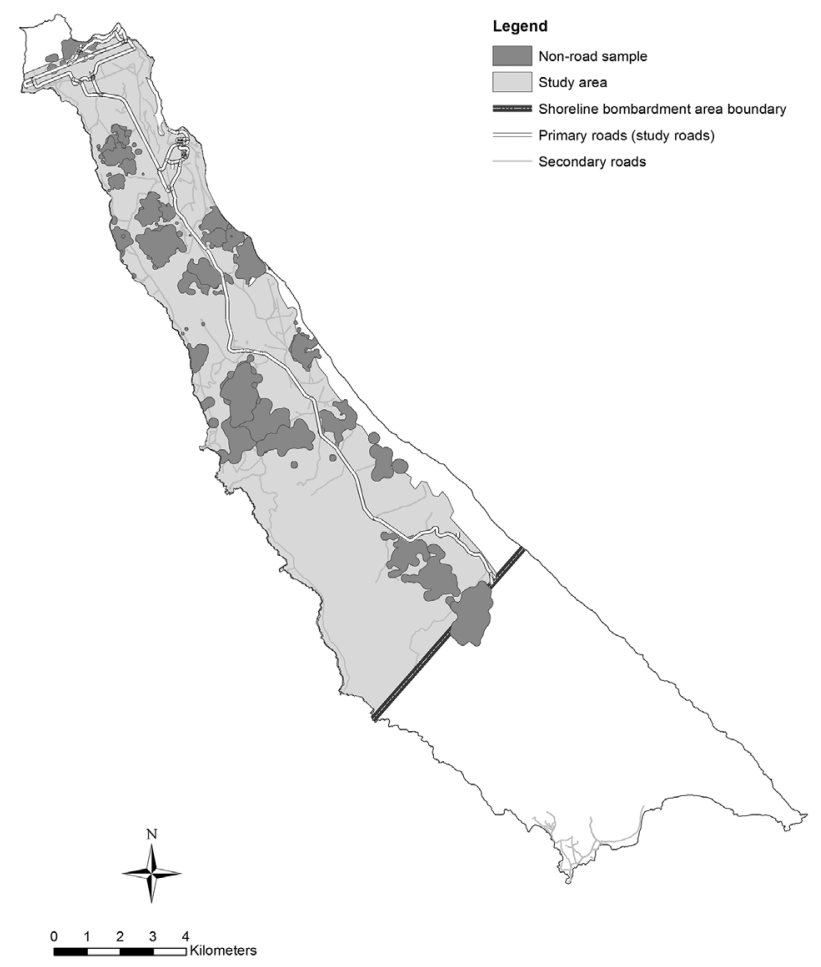

Figure 4. Island foxes in the non-road study sample did not have home ranges that overlapped the primary road on San Clemente Island, California, USA, 2006-2007.

on or near roads (e.g., less obstructed views) than in natural habitat (such as tall grasses). Primary roads run along the spine of the island and vegetation community type could be a contributing factor in the difference we observed between home range sizes and movement distances in the road and nonroad fox populations. However, recent vegetation maps were not available to assess possible correlation between fox movements and vegetation community type.

Control of feral cats occurs on San Clemente Island along roads with spotlighting effective to a distance of $300 \mathrm{~m}$ (USN 2013). This control might reduce inter-species competition near roads and affect movement patterns of foxes. Molsher et al. (2017) reported that removing red foxes (which are twice the size of feral cats) from the landscape resulted in decreased home range size for feral cats. In contrast, on San Clemente Island where feral cats are twice the size of island foxes and are thought to dominate encounters, we found island fox home ranges were larger around roads (where feral cats were removed) than away from roads (where feral cats were not removed).

\section{MANAGEMENT IMPLICATIONS}

Roads, directly or indirectly, influenced fox movements in our study and should be considered in both proactive and reactive strategies for controlling spread of highly contagious diseases such as rabies and canine distemper on San Clemente Island. Our recommendations include using disease modeling to evaluate the use of increased widths of vaccination firewalls, the effect of vaccination firewalls

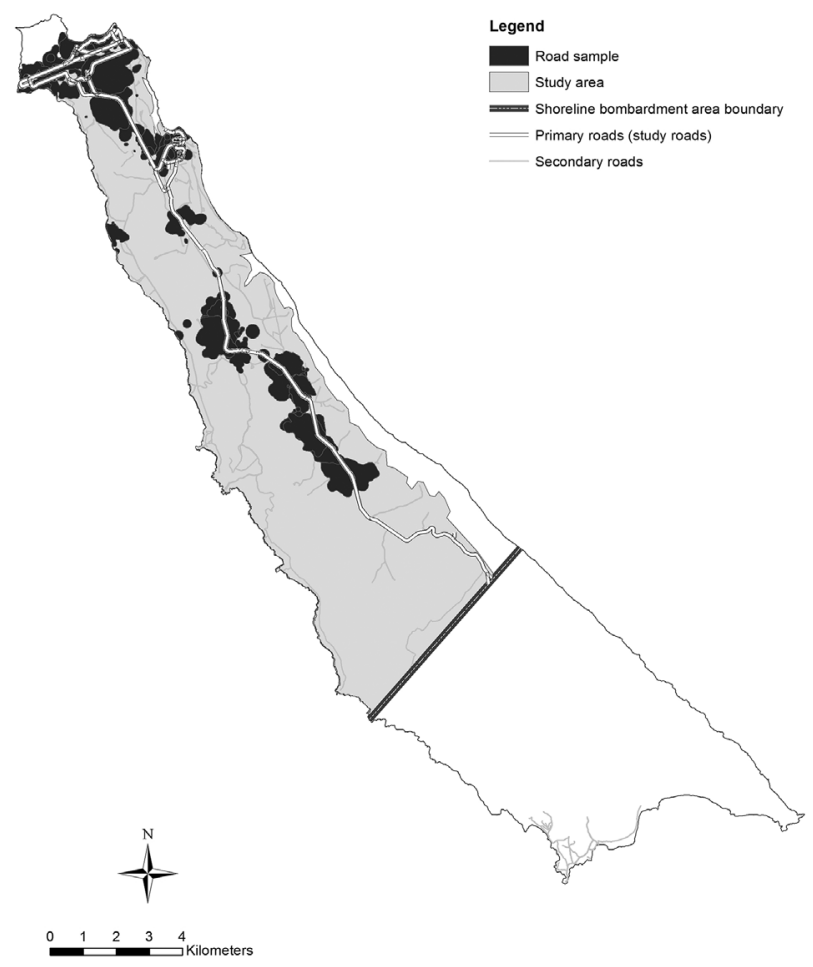

Figure 5. Island foxes in the road study sample had home ranges that overlapped the primary road on San Clemente Island, California, USA, 2006-2007.

that deliberately intersect roads, vaccinating a higher proportion of foxes living near roads, or ideally a strategy integrating all 3 management actions. Decisions ultimately depend on the risk tolerance of managers in addition to other considerations. Conservation strategies for different subspecies of island foxes could be better informed with subspeciesspecific spatial ecology studies.

\section{ACKNOWLEDGMENTS}

Any use of trade, firm, or product names is for descriptive purposes only and does not imply endorsement by the U.S. Government. We thank S. Barnhill, M. K. Brock, and R. A. Guieb for logistical support during the study. We are grateful to D. L. Clifford and T. W. Vickers for sharing their extensive knowledge of island fox biology. We thank D. K. Garcelon for sharing his experience studying island foxes over the past 2 decades. We thank C. Herbst, M-E. Jacques, V. Logsdon, M. Maley, and J. P. Purdum for their long hours collecting, entering, and proofing data. We thank the Institute for Wildlife Studies staff on San Clemente Island, particularly the Predator Research and Management division, for their help and cooperation throughout the study. We thank S. Baruch-Mordo, K. P. Burnham, P. L. Chapman, and A. J. Davis for statistical consultation, and D. E. Buttke for consultation on wildlife disease ecology and management. We thank M. A. Booker, L. Markovchick, J. A. Savidge, and D. M. Theobald for review of an earlier version of this manuscript. Funding was provided by the Department of the Navy on behalf of the Commander, 
Pacific Fleet, and the U.S. Geological Survey Fort Collins Science Center (for T. Stanley).

\section{LITERATURE CITED}

Adams, L., and S. D. Davis. 1967. The internal anatomy of home range. Journal of Mammalogy 48:529-536.

Adams, L. G., R. O. Stephenson, B. W. Dale, R. T. Ahgook, and D. J. Demma. 2008. Population dynamics and harvest characteristics of wolves in the Central Brooks Range, Alaska. Wildlife Monographs 170:1-25.

Appel, M. J. 1987. Virus infections of carnivores. Elsevier Science. Amsterdam, Netherlands.

Bingham, B. B., and B. R. Noon. 1997. Mitigation of habitat "take": application to habitat conservation planning. Conservation Biology 11:127-139.

Burdett, C., R. A. Moen, G. J. Niemi, and L. D. Mech. 2007. Defining space use and movements of Canada lynx with global positioning system telemetry. Journal of Mammalogy 88:457-467.

Burnham, K. P., and D. R. Anderson. 2002. Model selection and multimodel inference: a practical information-theoretic approach. Second edition. Springer-Verlag, New York, New York, USA.

Burt, W. H. 1943. Territoriality and home range concepts as applied to mammals. Journal of Mammalogy 24:346-352.

Cain, S. A. 1938. The species-area curve. American Midland Naturalist 19:573-581.

Cleaveland, S., C. Packer, K. Hampson, M. Kaare, R. Kock, M. Craft, T. Lembo, T. Mlengeya, and A. Dobson. 2008. The multiple roles of infectious disease in the Serengeti ecosystem. Pages 209-232 in A. R. E Sinclair, C. Packer, S. A. R. Mduma, and J. M. Fryxell, editors. Serengeti III: human impacts on ecosystem dynamics. University of Chicago Press, Chicago, Illinois, USA.

Clifford, D. L., J. A. K. Mazet, E. J. Dubovi, D. K. Garcelon, T. J. Coonan, P. A. Conrad, and L. Munson. 2006. Pathogen exposure in endangered island fox (Urocyon littoralis) populations: implications for conservation management. Biological Conservation 131:230-243.

Collins, P. W. 1987. Taxonomic and biogeographic relationships of the island fox (Urocyon littoralis) and gray fox (U. $c$ in ereoargenteus) from western North America. Pages 350-390 in F. G. Hoochberg, editor. Third California island symposium: recent advances in California islands research. Santa Barbara Museum of Natural History, Santa Barbara, California, USA.

Coonan, T. J. 2003. Recovery strategy for island foxes (Urocyon littoralis) on the northern Channel Islands. National Park Service, Channel Islands National Park, Ventura, California, USA.

Coonan, T. J. 2011. Thirteenth annual meeting - Island Fox Working Group, June 14-16 2011, summary report. Unpublished report on file at headquarters, Channel Islands National Park, Ventura, California, USA.

Coonan, T. J. 2012. Fourteenth annual meeting of the Island Fox Working Group, June 12-14 2012, summary report. Unpublished report on file at headquarters, Channel Islands National Park, Ventura, California, USA.

Coonan, T. J., C. A. Schwemm, G. W. Roemer, D. K. Garcelon, and L. Munson. 2005. Decline of an island fox subspecies to near extinction. Southwestern Naturalist 50:32-41.

Crooks, K. R. 1994. Demography and status of the island fox and the island spotted skunk on Santa Cruz Island, California. Southwestern Naturalist 39:257-262.

Crooks, K. R., and D. Van Vuren. 1996. Spatial organization of the island fox (Urocyon littoralis) on Santa Cruz Island, California. Journal of Mammalogy 77:801-806.

Daszak, P., A. A. Cunningham, and A. D. Hyatt. 2000. Emerging infectious diseases of wildlife - threats to biodiversity and human health. Science 287:443-449.

Dunn, J. E., and P. S. Gipson. 1977. Analysis of radio telemetry data in studies of home range. Biometrics 33:85-101.

Eisenberg, J. N. S., W. Cevallos, K. Ponce, K. Levy, S. J. Bates, J. C. Scott, A. Hubbard, N. Vieira, P. Endara, M. Espinel, G. Trueba, L. W. Riley, and J. Trostle. 2006. Environmental change and infectious disease: how new roads affect the transmission of diarrheal pathogen in rural Ecuador. Proceedings of the National Academy of Sciences 103:19460-19465.

Fausett, L. L. 1982. Activity and movement patterns of the island fox Urocyon littoralis, Baird 1857 (Carnivora: Canidae). Dissertation, University of California, Los Angeles, USA.
Fekadu, M. 1991. Canine rabies. Pages 367-378 in G. M. Baer, editor. The natural history of rabies (second edition). CRC Press, Boca Raton, Florida, USA

Garcelon, D. K., G. W. Roemer, R. B. Philips, and T. J. Coonan. 1999. Food provisioning by island foxes, Urocyon littoralis, to conspecifics caught in traps. Southwestern Naturalist 44:83-86.

Garcelon, D. K., R. K. Wayne, and B. J. Gonzales. 1992. A serologic survey of the island fox (Urocyon littoralis) on the Channel Islands, California. Journal of Wildlife Diseases 28:223-229.

Greenberg, D. B., and W. J. McClintock. 2008. Remember the third dimension: terrain modeling improves estimates of snake home range size. Copeia 4:801-806.

Hampson, K., J. Dushoff, S. Cleaveland, D. T. Haydon, M. Kaare, C. Packer, and A. Dobson. 2009. Transmission dynamics and prospects for the elimination of canine rabies. PLOS Biology 7(3):e1000053.

Harris, S., W. J. Cresswell, P. G. Forde, W. J. Trewhella, T. Woollard, and S. Wray. 1990. Home-range analysis using radio-tracking data-a review of problems and techniques particularly as applied to the study of mammals. Mammal Review 20:97-123.

Hayne, D. W. 1949. Calculation of size of home range. Journal of Mammalogy 30:1-18.

Hess, G. R. 1994. Conservation corridors and contagious disease: a cautionary note. Conservation Biology 8:256-262.

Hess, G. R. 1996. Disease in metapopulation models: implications for conservation. Ecology 77:1617-1632.

Hooge, P. N., and B. Eichenlaub. 2000. Animal movement extension to ArcView ver. 2.04 beta. Alaska Science Center-Biological Science Office, United States Geological Survey, Anchorage, Alaska, USA.

Huijser, M. P., and A. P. Clevenger. 2006. Habitat and corridor function of rights-of-way. Pages 233-254 in J. Davenport and J. L. Davenport, editors. The ecology of transportation: managing mobility for the environment. Springer, Dordrecht, Netherlands.

Jenness, J. S. 2004. Calculating landscape surface area from digital elevation models. Wildlife Society Bulletin 32:829-839.

Kaufmann, J. H. 1962. Ecology and social behavior of the coati, Nasua nirica, on Barro Colorado Island, Panama. University of California Publications in Zoology 60:95-222.

Kenward, R. 2001. Historical and practical perspectives. Pages 3-12 in J. J. Millspaugh and J. M. Marzluff, editors. Radio tracking and animal populations. Academic Press, San Diego, California, USA.

Kernohan, B. J., R. A. Gitzen, and J. M. Millspaugh. 2001. Analysis of animal space use and movements. Pages 125-166 in J. J. Millspaugh and J. M. Marzluff, editors. Radio tracking and animal populations. Academic Press, San Diego, California, USA.

Kitchen, A. M., E. M. Gese, S. M. Karke, and E. R. Schauster. 2005. Spatial ecology of swift fox social groups: from group formation to mate loss. Journal of Mammalogy 86:547-554.

Kohlmann, S. G., G. A. Schmidt, and D. K. Garcelon. 2005. A population viability analysis for the island fox on Santa Catalina Island, California. Ecological Modelling 183:77-94

Laughrin, L. L. 1977. The island fox; a field study of its behavior and ecology. Dissertation, University of California, Santa Barbara, USA.

Laver, P. N., and M. J. Kelly. 2008. A critical review of home range studies. Journal of Wildlife Management 72:290-298.

Marquardt G. 2005. Water, wood and wild animal populations: seeing the spread of rinderpest through the physical environment in Bechuanaland, 1896. South African Historical Journal 53:73-98.

Millspaugh, J. J., R. A. Gitzen, B. J. Kernohan, M. A. Larson, and C. L. Clay. 2004. Comparability of three analytical techniques to assess joint space use. Wildlife Society Bulletin 34:148-157.

Molsher, R., A. E. Newsome, T. M. Newsome, and C. R. Dickman. 2017. Mesopredator management: effects of red fox control on the abundance, diet and use of space by feral cats. PLoS ONE 12(1):e0168460. https:// doi.org/10.1371/journal.pone.0168460

Moore, D. A. 1999. Spatial diffusion of raccoon rabies in Pennsylvania, USA. Preventative Veterinary Medicine 40:19-32.

Odum, E. P., and E. J. Kuenzler. 1955. Measurement of territory and home range size in birds. Auk 72:128-137.

Olmstead, F. H. 1958. Geologic reconnaissance of San Clemente Island, California. Geological Survey Bulletin 1071-B, Washington, D.C., USA. 
Patz, J. A., P. Daszak, G. M. Tabor, A. A. Aguirre, M. Pearl, J. Epstein, N. D. Wolfe, A. M. Kilpatrick, J. Foufopoulos, D. Molyneux, D. J. Bradley, and Members of the Working Group on Land Use Change and Disease Emergence. 2004. Unhealthy landscapes: policy recommendations on land use change and infectious disease emergence. Environmental Health Perspectives 112:1092-1098.

Pauza, M. D., M. M. Driessen, and L. F. Skerratt. 2010. Distribution and risk factors for spread of amphibian chytrid fungus Batrachochytrium dendrobatidis in the Tasmanian Wilderness World Heritage Area, Australia. Diseases of Aquatic Organisms 92:193-199.

Pedersen, A. B., K. E. Jones, C. L. Nunn, and S. Altizer. 2007. Infectious disease and extinction risk in wild mammals. Conservation Biology 21:1269-1279.

Powell, R. A. 2000. Animal home ranges and territories and home range estimators. Pages 65-103 in L. Boitani and T. K. Fuller, editors. Research techniques in animal ecology: controversies and consequences. Columbia University Press, New York, New York, USA.

Powell, R. A., and M. S. Mitchell. 1998. Topographic constraints and home range quality. Ecography 21:337-371.

Resnik, J. R. 2012. Home range, site fidelity, reproductive ecology, and den site characteristics of the San Clemente Island fox. Thesis, Colorado State University, Fort Collins, USA.

Resnik, J. R., and W. F. Andelt. 2012. Reproductive ecology and den site characteristics of the San Clemente Island fox. Southwestern Naturalist;57:170-175.

Robinson, S., M. D. Samuel, R. E. Rolley, and P. Shelton. 2013. Using landscape epidemiological models to understand the distribution of chronic wasting disease in the Midwestern USA. Landscape Ecology: 1923-1935.

Roemer, G. W., T. J. Coonan, D. K. Garcelon, J. Bascompte, and L. Laughrin. 2001a. Feral pigs facilitate hyperpredation by golden eagles and indirectly cause the decline of the island fox. Animal Conservation 4:307-318.

Roemer, G. W., D. A. Smith, D. K. Garcelon, and R. K. Wayne. 2001b. The behavioural ecology of the island fox (Urocyon littoralis). Journal of Zoology, London 255:1-14.

Rosatte, R. C., D. Donovan, M. Allan, L. Bruce, T. Buchanan, K. Sobey, B. Stevenson, M. Gibson, T. MacDonald, M. Whalen, J. C. Davies, F. Muldoon, and A. Wandeler. 2009. The control of raccoon rabies in Ontario Canada: proactive and reactive tactics, 1994-2007. Journal of Wildlife Diseases 45:772-784.

Rosatte, R., D. Donovan, M. Allan, L-A. Howes, A. Silver, K. Bennett, C. MacInnes, C. Davies, A. Wandeler, and B. Radford. 2001. Emergency response to raccoon rabies introduction into Ontario. Journal of Wildlife Diseased 37:265-279.

Rosatte, R., M. Ryckman, K. Ing, S. Proceviat, M. Allan, L. Bruce, D. Donovan, and J. C. Davies. 2010. Density, movements, and survival of raccoons in Ontario, Canada: implications for disease spread and management. Journal of Mammalogy 91:122-135.

Rubin, E. S., V. J. Bakker, M. G. Efford, B. S. Cohen, F. A. Stallcup, W. D. Spencer, and S. A. Morrison. 2007. A population monitoring framework for five subspecies of island fox (Urocyon littoralis). Conservation Biology Institute, Corvallis, Oregon, USA.

Russell, C. A., D. L. Smith, L. A. Waller, J. E. Childs, and L. A. Real. 2004. A priori prediction of disease invasion dynamics in a novel environment. Proceedings of the Royal Society of London, Biological Sciences Series 271:21-25.

Samuel, M. D., D. J. Pierce, and E. O. Garton. 1985. Identifying areas of concentrated use within the home range. Journal of Animal Ecology 54:711-719.

Sanchez, J. 2012. Spatial ecology of disease spread in the island fox. Thesis, Humboldt State University, Arcata, California, USA.

Schoenherr, A. A., C. R. Fedmeth, and M. J. Emerson. 1999. Natural history of the islands of California. University of California Press, Berkeley, USA.

Seaman, D. E., J. J. Millspaugh, B. J. Kernohan, G. C. Brundige, K. J. Raedeke, and R. A. Gitzen. 1999. Effects of sample size on kernel home range estimates. Journal of Wildlife Management 63:739-747.

Seaman, D. E., and R. A. Powell. 1996. An evaluation of the accuracy of kernel density estimators for home range analysis. Ecology 77: 2075-2085.
Seber, G. A. F. 1982. The estimation of animal abundance and related parameters. Second edition. Charles Griffin, London, United Kingdom. Silverman, B. W. 1986. Density estimation for statistics and data analysis. Chapman and Hall, New York, New York, USA.

Skuldt, L. H., N. E. Mathews, and A. M. Oyer. 2008. White-tailed deer movements in a chronic wasting disease area in South-Central Wisconsin. Journal of Wildlife Management 72:1156-1160.

Slate, D., C. E. Rupprecht, J. A. Rooney. D. Donovan, D. H. Lein, and R. B. Chipman. 2005. Status of oral rabies vaccination in wild carnivores in the United States. Virus Research 111:68-76.

Smith, K., A. Krogwold, R. Smith, F. Hale, R. Collart, and M. Craig. 1999. The Ohio ORV Program. Proceedings of Rabies in the Americas, San Diego, California, USA.

Snow, N. P., and W. F. Andelt. 2013. Capture success higher near roads for San Clemente Island foxes. Wildlife Society Bulletin 37:623-630.

Snow, N. P., W. F. Andelt, T. R. Stanley, J. R. Resnik, and L. Munson. 2012. Effects of roads on survival of San Clemente Island foxes. Journal of Wildlife Management 76:243-252.

Sterner, R. T., and G. C. Smith. 2006. Modelling wildlife rabies: transmission, economics, and conservation. Biological Conservation 131: 163-179.

Storm, G. L., R. D. Andrews, R. L. Phillips, R. A. Bishop, D. B. Siniff, and J. R. Tester. 1976. Morphology, reproduction, dispersal, and mortality of midwestern red fox populations. Wildlife Monographs 49:3-82.

Theobald, D. M., D. L. Stevens Jr., D. White, D. S. Urquhart, A. R. Olsen, and J. B. Norman. 2007. Using GIS to generate spatially balanced random survey designs for natural resource applications. Environmental Management 40:134-146.

Timischl, W. 1984. Influence of landscape on the spread of an infection. Bulletin of Mathematical Biology 46:869-877.

Timm, S. F., L. Munson, B. A. Summers, K. A. Terio, E. J. Dubovi, C. E. Rupprecht, S. Kapil, and D. K. Garcelon. 2009. A suspected canine distemper epidemic as the cause of a catastrophic decline in Santa Catalina Island foxes (Urocyon littoralis catalinae). Journal of Wildlife Disease 45:333-343

Trewhella, W. J., and S. Harris. 1990. The effect of railway lines on urban fox (Vulpes vulpes numbers and dispersal movements. Journal of Zoology 221:321-326.

U.S. Naval Observatory. 2014. Astronomical applications department - Data services. $<$ http://aa.usno.navy.mil/data/index.php $>$. Accessed 04 Feb 2017.

U.S. Navy [USN]. 2013. Integrated Natural Resources Management Plan: Naval Auxiliary Landing Field San Clemente Island - Final, June 2013. Tierra Data Inc., Escondido, California, USA.

Urban, M. C. 2006. Road facilitation of trematode infections in snails of northern Alaska. Conservation Biology 20:1143-1149.

Van Winkle, W. 1975. Comparison of several probabilistic home-range models. Journal of Wildlife Management 39:118-123.

White, G. C., and R. A. Garrott. 1990. Analysis of wildlife radio-tracking data. Academic Press, San Diego, California, USA.

Wobeser, G. A. 2007. Disease in wild animals: investigation and management. Second edition. Springer-Verlag, Berlin, Germany.

Wood, J. E. 1958. Age structure and productivity of a gray fox population. Journal of Mammalogy 39:74-86.

Woodroffe, R., K. C. Prager, L. Munson, P. A. Conrad, E.J. Dubovi, andJ. A. K. Mazet. 2012. Contact with domestic dogs increases pathogen exposure in endangered African wild dogs (Lycaon pictus). PLoS ONE 7:e30099.

Worton, B. J. 1987. A review of models of home range for animal movement. Ecological Modelling 38:277-298.

Worton, B. J. 1989. Kernel methods for estimating the utilization distribution in home-range studies. Ecology 70:164-168.

Wyckoff, A. C., S. E. Henke, T. A. Campbell, D. G. Hewitt, and K. C. VerCauteren. 2012. Movement and habitat use of feral swine near domestic swine facilities. Wildlife Society Bulletin 36:130-138.

Xu L., L. C. Stige, K. L. Kausrud, T. B. Ari, S. Wang, X. Fang, B. V. Schmid, Q. Liu, N. C. Stenseth, and Z. Zhang. 2014. Wet climate and transportation routes accelerate spread of human plague. Proceedings of the Royal Society of London B: Biological Sciences 281:1-9.

Associate Editor: John Squires. 
APPENDIX A. MODEL SELECTION RESULTS.

Table A. Model selection results for predictors of annual and seasonal home range and core area sizes for an island-wide sample of San Clemente Island foxes, California, USA, 2006-2007. Mean differences in least squares means $(\Delta)$ with associated $95 \%$ confidence intervals $(\mathrm{CI})$ are provided only for the top model of each analysis.

\begin{tabular}{|c|c|c|c|c|}
\hline Models & $K^{\mathrm{a}}$ & $\mathrm{AIC}_{c}$ & $w_{i}$ & $\Delta(95 \% \text { CI })^{b}$ \\
\hline \multicolumn{5}{|c|}{ Annual home range } \\
\hline Sex & 3 & 56.4 & 0.81 & \multirow[t]{2}{*}{$\begin{array}{c}\Delta_{\mathrm{F}-\mathrm{M}}=0.13 \\
(-0.31 \text { to } 0.57)\end{array}$} \\
\hline Age & 4 & 59.3 & 0.19 & \\
\hline \multicolumn{5}{|c|}{ Annual core area } \\
\hline Sex & 3 & 61.6 & 0.80 & \multirow[t]{2}{*}{$\begin{array}{c}\Delta_{\mathrm{F}-\mathrm{M}}=0.10 \\
(-0.38 \text { to } 0.58)\end{array}$} \\
\hline Age & 4 & 64.4 & 0.20 & \\
\hline \multicolumn{5}{|c|}{ Seasonal home range $\mathrm{e}^{\mathrm{c}}$} \\
\hline \multirow[t]{3}{*}{ Season } & \multirow[t]{3}{*}{4} & \multirow[t]{3}{*}{119.7} & \multirow[t]{3}{*}{0.87} & $\begin{array}{l}\Delta_{\text {Ind-Dep }}=0.20 \\
(0.004 \text { to } 0.39)\end{array}$ \\
\hline & & & & $\begin{array}{r}\Delta_{\text {Ind-Brd }}=0.24 \\
(0.07 \text { to } 0.40)\end{array}$ \\
\hline & & & & $\begin{array}{c}\Delta_{\text {Brd-Dep }}=-0.04 \\
(-0.18 \text { to } 0.10)\end{array}$ \\
\hline Sex & 3 & 123.9 & 0.11 & \\
\hline Age & 4 & 127.0 & 0.02 & \\
\hline \multicolumn{5}{|c|}{ Seasonal core area $^{\mathrm{d}}$} \\
\hline \multirow[t]{3}{*}{ Season } & 4 & 167.7 & 0.46 & $\begin{array}{l}\Delta_{\text {Ind-Dep }}=0.20 \\
(-0.03 \text { to } 0.42)\end{array}$ \\
\hline & & & & $\begin{array}{l}\Delta_{\text {Ind-Brd }}=0.17 \\
(-0.10 \text { to } 0.43)\end{array}$ \\
\hline & & & & $\begin{array}{l}\Delta_{\text {Brd-Dep }}=0.03 \\
(-0.20 \text { to } 0.26)\end{array}$ \\
\hline Sex & 3 & 168.1 & 0.38 & \\
\hline Age & 4 & 169.9 & 0.15 & \\
\hline
\end{tabular}

a $K=$ Number of model parameters, $\mathrm{AIC}_{c}=$ Akaike's Information Criterion values corrected for small sample sizes, and $w_{i}=$ weight of evidence for being the best approximating model.

${ }^{\mathrm{b}}$ We report differences between sexes (female $[\mathrm{F}]$ and male $[\mathrm{M}]$ ) and seasons: breeding (Brd), pup-dependence (Dep), and pup-independence (Ind).

c Post hoc models: season $+\operatorname{sex}\left(K=5, \quad \mathrm{AIC}_{c}=121.5, w_{i}=0.24\right)$; season $+\operatorname{sex}+($ season $\times \operatorname{sex})\left(K=7, \mathrm{AIC}_{c}=123.7, w_{i}=0.08\right)$. Season remained top model with $w_{i}=0.59$.

d Post hoc models: season $+\operatorname{sex}\left(K=5, \quad \mathrm{AIC}_{c}=170.3, w_{i}=0.11\right)$; season $+\operatorname{sex}+($ season $\times \operatorname{sex})\left(K=7, \mathrm{AIC}_{c}=173.6, w_{i}=0.02\right)$. Season remained top model with $w_{i}=0.40$.
Table B. Model selection results for predictors of annual and seasonal home range and core area sizes for road and non-road samples of San Clemente Island foxes, California, USA, 2006-2007. Mean differences in least squares means $(\Delta)$ with associated $95 \%$ confidence intervals $(\mathrm{CI})$ are provided only for the top model of each analysis.

\begin{tabular}{|c|c|c|c|c|}
\hline Models & $K^{\mathrm{a}}$ & $\mathrm{AIC}_{c}$ & $w_{i}$ & $\Delta(95 \% \mathrm{CI})^{\mathrm{b}}$ \\
\hline \multicolumn{5}{|c|}{ Annual home range } \\
\hline Road & 3 & 63.8 & 0.99 & \multirow[t]{3}{*}{$\begin{array}{c}\Delta_{\mathrm{Rd}-\mathrm{Non}}=0.59 \\
(0.24 \text { to } 0.94)\end{array}$} \\
\hline Sex & 3 & 74.0 & 0.01 & \\
\hline Age & 4 & 75.5 & 0.00 & \\
\hline \multicolumn{5}{|c|}{ Annual core area } \\
\hline Road & 3 & 68.4 & 0.98 & \multirow[t]{3}{*}{$\begin{array}{r}\Delta_{\mathrm{Rd}-\mathrm{Non}}=0.57 \\
(0.20 \text { to } 0.95)\end{array}$} \\
\hline Sex & 3 & 77.0 & 0.01 & \\
\hline Age & 4 & 78.7 & 0.01 & \\
\hline \multicolumn{5}{|c|}{ Seasonal home range $\mathrm{c}^{\mathrm{c}}$} \\
\hline Road & 3 & 157.8 & 0.99 & \multirow[t]{4}{*}{$\begin{array}{c}\Delta_{\mathrm{Rd}-\mathrm{Non}}=0.64 \\
(0.34 \text { to } 0.94)\end{array}$} \\
\hline Season & 4 & 167.5 & 0.01 & \\
\hline Sex & 3 & 168.5 & 0.00 & \\
\hline Age & 4 & 170.7 & 0.00 & \\
\hline \multicolumn{5}{|c|}{ Seasonal core area ${ }^{\mathrm{d}}$} \\
\hline Road & 3 & 214.1 & 0.94 & \multirow[t]{4}{*}{$\begin{array}{r}\Delta_{\mathrm{Rd}-\mathrm{Non}}=0.47 \\
(0.14 \text { to } 0.81)\end{array}$} \\
\hline Sex & 3 & 221.3 & 0.03 & \\
\hline Age & 4 & 222.2 & 0.02 & \\
\hline Season & 4 & 222.5 & 0.01 & \\
\hline
\end{tabular}

a $K=$ Number of model parameters, $\mathrm{AIC}_{c}=$ Akaike's Information Criterion values corrected for small sample sizes, and $w_{i}=$ weight of evidence for being the best approximating model.

${ }^{\mathrm{b}}$ We divided the year into 3 seasons: breeding (Brd), pup-dependence (Dep), and pup-independence (Ind). Foxes had a home range either overlapping (road sample; Rd) or not overlapping (Non-road sample; Non) a road.

${ }^{c}$ Post hoc models: road + season $+(\operatorname{road} \times$ season $)\left(K=7, \mathrm{AIC}_{c}=149.6\right.$, $w_{i}=0.97$; new top model), $\Delta_{\text {RdBrd-NonBrd }}=0.72$ (0.33 to 1.11), $\Delta_{\text {RdInd- }}$ NonInd $=0.52$ (0.20 to 0.83$), \Delta_{\text {RdDep-NonDep }}=0.23$ ( -0.18 to 0.65$)$; road $\left(\mathrm{AIC}_{c}=157.8, w_{i}=0.02\right)$; road + season $\left(\mathrm{AIC}_{c}=158.9, w_{i}=0.01\right)$.

$\mathrm{d}$ Post hoc models: road + season $+($ road $\times$ season $)\left(K=7, \mathrm{AIC}_{c}=216.8\right.$, $\left.w_{i}=0.17\right)$; road + season $\left(\mathrm{AIC}_{c}=217.5, w_{i}=0.12\right)$; road remained top model with $w_{i}=0.67$ 
Table C. Model selection results for predictors of site fidelity among seasonal home ranges or core areas for island-wide, road, and non-road samples of San Clemente Island foxes, California, USA, 2006-2007. Mean differences in least squares means $(\Delta)$ with associated $95 \%$ confidence intervals $(\mathrm{CI})$ are provided only for the top model of each analysis.

\begin{tabular}{|c|c|c|c|c|}
\hline Models & $K^{\mathrm{a}}$ & $\mathrm{AIC}_{c}$ & $w_{i}$ & $\Delta(95 \% \text { CI })^{b}$ \\
\hline \multicolumn{5}{|c|}{ Island-wide sample } \\
\hline \multicolumn{5}{|c|}{ All seasonal home ranges } \\
\hline Sex & 3 & -47.5 & 0.98 & \multirow[t]{2}{*}{$\begin{array}{c}\Delta_{\mathrm{F}-\mathrm{M}}=-0.09 \\
(-0.17 \text { to }-0.02)\end{array}$} \\
\hline Age & 4 & -39.7 & 0.02 & \\
\hline \multicolumn{5}{|c|}{ All seasonal core areas } \\
\hline Sex & 3 & -56.9 & 0.76 & \multirow[t]{2}{*}{$\begin{array}{c}\Delta_{\mathrm{F}-\mathrm{M}}=0.01 \\
(-0.05 \text { to } 0.07)\end{array}$} \\
\hline Age & 4 & -54.6 & 0.24 & \\
\hline \multicolumn{5}{|c|}{ Road and non-road samples } \\
\hline \multicolumn{5}{|c|}{ All seasonal home ranges } \\
\hline Sex & 3 & -51.1 & 0.62 & \multirow[t]{3}{*}{$\begin{array}{l}\Delta_{\mathrm{F}-\mathrm{M}}=-0.06 \\
(-0.13 \text { to } 0.02)\end{array}$} \\
\hline Road & 3 & -49.7 & 0.31 & \\
\hline Age & 4 & -46.9 & 0.08 & \\
\hline \multicolumn{5}{|c|}{ All seasonal core areas } \\
\hline Road & 3 & -78.4 & 0.74 & \multirow[t]{3}{*}{$\begin{array}{r}\Delta_{\mathrm{Rd}-\mathrm{Non}}=-0.05 \\
(-0.10 \text { to } 0.01)\end{array}$} \\
\hline Sex & 3 & -75.8 & 0.20 & \\
\hline Age & 4 & -73.4 & 0.06 & \\
\hline
\end{tabular}

a $K=$ Number of model parameters, $\mathrm{AIC}_{c}=$ Akaike's Information Criterion values corrected for small sample sizes, and $w_{i}=$ weight of evidence for being the best approximating model.

${ }^{\mathrm{b}}$ We report differences between sexes (female $[\mathrm{F}]$ and male $[\mathrm{M}]$ ) and sample. Foxes had a home range either overlapping (road sample; Rd) or not overlapping (Non-road sample; Non) a study road. The island-wide sample consisted of all non-road foxes and a subset of road foxes.
Table D. Model selection results for predictors of movement distances of island-wide, road, and non-road samples of San Clemente Island foxes, California, USA, 2006-2007. Mean differences in least squares means $(\Delta)$ with associated $95 \%$ confidence intervals (CI) are provided only for the top model of each analysis.

\begin{tabular}{|c|c|c|c|c|}
\hline Models & $K^{\mathrm{a}}$ & $\mathrm{AIC}_{c}$ & $w_{i}$ & $\Delta(95 \% \text { CI })^{b}$ \\
\hline \multicolumn{5}{|l|}{ Island-wide sample } \\
\hline \multirow[t]{6}{*}{ Diel_DDDN $^{c}$} & 117 & 1524 & $100 \%$ & $\begin{array}{c}\Delta_{\text {Day-Dawn }}=-1.21 \\
(-1.69 \text { to }-0.74)\end{array}$ \\
\hline & & & & $\begin{array}{l}\Delta_{\text {Day-Dusk }}=-1.16 \\
(-1.60 \text { to }-0.73)\end{array}$ \\
\hline & & & & $\begin{array}{c}\Delta_{\text {Day-Night }}=-1.47 \\
(-1.80 \text { to }-1.14)\end{array}$ \\
\hline & & & & $\begin{array}{l}\Delta_{\text {Dawn-Dusk }}=0.05 \\
(-0.50 \text { to } 0.61)\end{array}$ \\
\hline & & & & $\begin{array}{l}\Delta_{\text {Dawn-Night }}=-0.25 \\
\quad(-0.73 \text { to } 0.22)\end{array}$ \\
\hline & & & & $\begin{array}{l}\Delta_{\text {Dusk-Night }}=-0.30 \\
\quad(-0.74 \text { to } 0.13)\end{array}$ \\
\hline Diel_DNC & 88 & 1544 & $0 \%$ & \\
\hline $\begin{array}{c}\text { Diel_DNC | } \\
\text { season }\end{array}$ & 262 & 1644 & $0 \%$ & \\
\hline $\begin{array}{l}\text { Diel_DDDN | } \\
\text { season }\end{array}$ & 346 & 1692 & $0 \%$ & \\
\hline Diel_DN & 59 & 1768 & $0 \%$ & \\
\hline Sex & 30 & 2368 & $0 \%$ & \\
\hline Season & 88 & 2433 & $0 \%$ & \\
\hline \multicolumn{5}{|l|}{$\begin{array}{l}\text { Road and non- } \\
\text { road samples }\end{array}$} \\
\hline \multirow[t]{4}{*}{$\begin{array}{l}\text { Road | } \\
\text { Diel_DDDN }\end{array}$} & 149 & 2081 & $100 \%$ & $\begin{array}{l}\Delta_{\text {RdDay-NonDay }}=0.03 \\
\quad(-0.44 \text { to } 0.49)\end{array}$ \\
\hline & & & & $\begin{array}{c}\Delta_{\text {RdDawn-NonDawn }}=0.25 \\
\quad(-0.64 \text { to } 1.13)\end{array}$ \\
\hline & & & & $\begin{array}{c}\Delta_{\text {RdDusk-NonDusk }}=1.03 \\
\quad(0.29 \text { to } 1.76)\end{array}$ \\
\hline & & & & $\begin{array}{c}\Delta_{\text {RdNight-NonNight }}=0.09 \\
\quad(-0.37 \text { to } 0.55)\end{array}$ \\
\hline Road & 38 & 3336 & $0 \%$ & \\
\hline
\end{tabular}

a $K=$ Number of model parameters, $\mathrm{AIC}_{c}=$ Akaike's Information Criterion values corrected for small sample sizes, and $w_{i}=$ weight of evidence for being the best approximating model.

${ }^{b}$ Foxes had a home range either overlapping (road sample; Rd) or not overlapping (Non-road sample; Non) a study road. The island-wide sample consisted of all non-road foxes and a subset of road foxes.

${ }^{\mathrm{c}}$ We divided the 24-hour diel period into 2 segments ( $\mathrm{DN}=$ day, night); 3 segments $(\mathrm{DNC}=$ day, night, crepuscular); or 4 segments $(\mathrm{DDDN}=$ dawn, day, dusk, night).

${ }^{\mathrm{d}}$ We divided the year into 3 seasons: breeding, pup-dependence, and pupindependence.

e The bar symbol $(\mid)$ denotes a model with main effects and an interaction term 